Proc. Estonian Acad. Sci. Geol., 1997, 46, 1, 42-55

\title{
CARBON GEOCHEMISTRY IN RELATION TO SEDIMENT CHRONOLOGY OF LAKE KAHALA
}

\author{
Raivo RAJAMÄE, Leili SAARSE, Tõnu MARTMA, Atko HEINSALU, \\ Anneli POSKA, and Siim VESKI
}

Geoloogia Instituut (Institute of Geology), Estonia pst. 7, EE-0001 Tallinn, Eesti (Estonia)

Presented by A. Raukas

Received 20 August 1996, accepted 24 January 1997

\begin{abstract}
An attempt was made to use the conventional radiocarbon dating technique with a geochemical approach for assessing the reliability of datings on bulk sedimentary organic matter in a study of sediment chronology of Lake Kahala, North Estonia. For the reconstruction of changes in the carbon geochemical cycle in the lake, $\delta^{13} \mathrm{C}$ and $\mathrm{C}: \mathrm{N}$ of sedimentary organic matter, sediment composition, content of macroremains, and ${ }^{210} \mathrm{~Pb}$ datings were used. The study revealed an increase in lake productivity at the stage of the accumulation of organic gyttja associated with a higher input of autochthonous organic matter to sediments. Enrichment of sedimentary organic matter in ${ }^{13} \mathrm{C}$ indicates that dissolved organic carbon in the lake water was nearly in isotopic equilibrium with the atmospheric $\mathrm{CO}_{2}$ and that ${ }^{14} \mathrm{C}$ datings show high validity. This conclusion is supported by the fact that ${ }^{14} \mathrm{C}$ ages of local pollen assemblage zones in the depth interval of $1.0-5.7 \mathrm{~m}$ are in accordance with the chronology of the regional pollen stratigraphy. Scattering of ${ }^{14} \mathrm{C}$ datings on the upper $1.0 \mathrm{~m}$ of sediment refers to desultory sedimentation of gyttja caused by subsurface erosion and redeposition processes. Still, ${ }^{210} \mathrm{~Pb}$ data testify to a continuous sediment accumulation, in this century having the mean rate as high as $2.5 \mathrm{~mm} / \mathrm{yr}$.
\end{abstract}

Key words: radiocarbon and ${ }^{210} \mathrm{~Pb}$ dates, sediment geochemistry.

\section{INTRODUCTION}

The radiocarbon method continues to be the favoured dating technique in palaeoenvironmental and geochronological investigations. However, it has long been known that radiocarbon dates of lake sediments may be affected by old carbon which can produce dates that are too old (Håkansson, 1979; Olsson, 1986). The geochemical background for this is that the lake sediments consist 
of the material containing carbon of a lower ${ }^{14} \mathrm{C}$ concentration than the contemporary atmospheric one. Carbon of different origin could be transported into the lake by groundwater mainly as dissolved inorganic carbon (DIC) or as dissolved or detrital organic material by surface water from the catchment, but also as $\mathrm{CO}_{2}$ gas from the atmosphere and organic-rich bottom sediments. The ratio of carbon flows and their isotopic composition is specific for each lake and may largely change during lake development.

DIC in the lake water is in isotopic equilibrium with the atmospheric $\mathrm{CO}_{2}$ (Turner et al., 1983) only in exceptional cases or when sedimentary organic matter originates from the contemporaneous terrestrial material, which yields correct ${ }^{14} \mathrm{C}$ dates. Very often the carbon cycle may be stationary for a relatively long time. It means that the ${ }^{14} \mathrm{C}$ initial concentration of the settling material was constant but might have had a lower value than the atmospheric one. Datings on the corresponding sediments show an apparent ${ }^{14} \mathrm{C}$ age, i.e. they have a systematic error. Measuring the error for some layer, we can elaborate a reliable chronology for this sediment depth interval. In many lakes, however, the carbon cycle has undergone continuous alterations in the course of time, which caused changes in the error of an apparent ${ }^{14} \mathrm{C}$ age. To assess the validity of dates or to find reliable corrections, criteria are needed indicating in which state the carbon cycle was.

For this purpose the most informative seems to be the $\delta^{13} \mathrm{C}$ value of the material investigated. As the $\delta^{13} \mathrm{C}$ of source carbon, transported into a lake from different reservoirs, shows large discrepancies (Buchardt \& Fritz, 1980), this parameter on bulk sedimentary organic matter is very sensitive to changes in the ratio of carbon flows and reflects also changes in the initial concentration of ${ }^{14} \mathrm{C}$ in the depositing material. The $\delta^{13} \mathrm{C}$ of autochthonous organic matter depends on the isotopic effects in the assimilation of inorganic carbon in photosynthesis and is therefore largely modulated by the biological and trophical development in the lake. The corresponding minor changes of ${ }^{14} \mathrm{C}$ initial activity of bulk sedimentary organic matter cause relatively small errors in radiocarbon age. On the other hand, $\delta^{13} \mathrm{C}$ does not reflect lowering in the ${ }^{14} \mathrm{C}$ concentration of allochthonous organic matter eroded from soils and sediments of older age. Thus, the $\delta^{13} \mathrm{C}$ of bulk sedimentary organic matter is a problematic criterion for assessing the state of the carbon cycle in the past and, consequently, the validity of radiocarbon datings. It should be supported by sediment parameters recorded by palaeoprocesses and by palaeolimnological, geological, hydrological, etc. information.

The main purpose of this study was to elaborate the chronology of sediment accumulation in Lake Kahala. To realize this objective, one possibility was to separate and apply AMS technique to date terrestrial macroremains, which, however, could be reworked and redeposited (Törnqvist et al., 1990). Thus, in this study an attempt is made to use the conventional dating technique with a geochemical approach to assess the reliability of datings. 


\section{STUDY SITE}

Lake Kahala $\left(59^{\circ} 29^{\prime} \mathrm{N}, 25^{\circ} 31^{\prime} \mathrm{E}\right)$ is located about $40 \mathrm{~km}$ east of Tallinn, near the Tallinn-Narva motorway, at the western corner of the Lahemaa National Park, not far from the klint escarpment. The lake measures $2.4 \mathrm{~km}$ in length, $2 \mathrm{~km}$ in width, $350 \mathrm{ha}$ in area, and the threshold elevation is $33.5-34.0 \mathrm{~m}$ a.s.1. It is surrounded by a peaty belt with striae of marine sand and silt outside it. The water level is regulated at $33.2 \mathrm{~m}$ a.s.l., the mean water depth is $1 \mathrm{~m}$, the maximum one $2.2 \mathrm{~m}$.

The bottom topography of Lake Kahala is rather regular. More than $90 \%$ of it is covered by gyttja, which reaches far beyond the present lake contour in the north and northwestern part, but misses in the northeastern belt. Gyttja is up to $6.5 \mathrm{~m}$ thick, underlain by silt, in the littoral zone also by sand (Saarse et al., in press).

\section{MATERIALS AND METHODS}

The sediment sample was taken from the main core No. 1-94 in May 1994 with a Limnos type sampler and Russian type peat corer (Saarse et al., in press). The content of organic matter was determined by the loss on ignition at $500{ }^{\circ} \mathrm{C}$ and that of carbonates by loss at $950^{\circ} \mathrm{C}$.

Radiocarbon datings and carbon isotopic investigations were performed in the Institute of Geology, Tallinn. Datings were obtained on bulk fine-grained (less than $0.7 \mathrm{~mm}$ ) organic matter using the conventional liquid scintillation counting method. All radiocarbon dates are normalized to $\delta^{13} \mathrm{C}$ of $-25 \%$ and reported as ${ }^{14} \mathrm{C}$ yr BP.

The carbon stable isotope composition was determined on Delta $\mathrm{E}$ mass spectrometer in carbon dioxide obtained from the sample organic material in a pretreatment line using the dynamic combustion method. The results are presented conventionally as per mil relative to the PDB standard. The estimated total standard error for $\delta^{13} \mathrm{C}$ values is about $0.5 \%$.

${ }^{210} \mathrm{~Pb}$ analysis was performed on subsamples from $5 \mathrm{~cm}$ depth intervals and containing $1-2 \mathrm{~g}$ of dry sediments. The ${ }^{210} \mathrm{~Pb}$ activity was detected via its granddaughter isotope ${ }^{210} \mathrm{Po}$ by the isotope dilution technique using ${ }^{208} \mathrm{Po}$ as a yield tracer (Varvas \& Punning, 1993). Activity values are presented as pCi per gram of dry sediment. The value of supported ${ }^{210} \mathrm{~Pb}$ has been estimated by the total ${ }^{210} \mathrm{~Pb}$ at lower depths on the core where this isotope and ${ }^{226} \mathrm{Ra}$ are assumed to be in equilibrium. The ${ }^{210} \mathrm{~Pb}$ dating was carried out in the Institute of Ecology by M. Varvas.

The H, C, and $\mathrm{N}$ analyses were made on the Hewlett Packard Type 185 microanalyser in the Institute of Chemistry by L. Lahe on $15-20 \mathrm{mg}$ of powdered sediment material. It was assumed that in case of organic-rich sediments the 
chemical data obtained on total material would represent mainly the elemental composition of the organic component of sediment. The calculated $\mathrm{C}: \mathrm{N}$ ratios express the weight ratio of these elements in sedimentary organic matter.

For the macroremain analysis, performed in the Institute of History by S. Hiie, gyttja was sieved through a $0.25 \mathrm{~mm}$ screen and plant remains were pretreated with warm $1 \% \mathrm{NaOH}$ solution before specifying under microscope. The plant macrofossil diagram presents the number for each species counted in 0.51 wet initial sediment.

\section{RESULTS AND INTERPRETATION}

Sediment composition. The water content of gyttja is nearly constant for the upper $2 \mathrm{~m}$, decreasing gradually towards lower depths (Fig. 1). A decrease in the water content and an increase in bulk density at a depth around $5 \mathrm{~m}$ indicate higher input of terrestrial minerogenic material. The organic matter content decreases down to $40 \%$ at this depth showing an increase in settling material eroded from land at a relatively low water level. The carbonate content of sediments is low despite the fact that the lake basin is located on the plateau of carbonate rocks and fed by hard groundwaters. At present, the content of DIC in lake water at $\mathrm{pH} 8.5$ is about $120 \mathrm{mg} / \mathrm{l}$. The X-ray structural investigations of sediment minerogenic component showed that part of carbonates are of secondary, thermal origin (Saarse et al., 1984). Thus, the amount of possible authigenic carbonates is less than was concluded by the loss of ignition, ranging within a few per cent.

Macrofossil analysis revealed an abrupt increase in limnophyte remains for the upper $60 \mathrm{~cm}$ layer which corresponds to the coarse detritus gyttja (Fig. 2). Obviously, this gyttja was formed under the conditions of a low water table and high trophic level. Lower sediments are extremely poor in macroremains, which refers to their autochthonous algal origin or total decomposition of detritus organic matter.

The $\mathbf{C}: \mathbf{N}$ ratio of sedimentary organic matter shows relatively small shifts (Fig. 1). The concentration of organic carbon and nitrogen depends on the character of the organic matter and on the decomposition processes that occurred during and after deposition. The $\mathrm{C}: \mathrm{N}$ ratio in living plankton is about 6 (Håkansson \& Jansson, 1983). In autochthonous organic matter, originating from the decomposition of plankton, this ratio usually varies between $8-12$, while colloidal and dissolved allochthonous matter often has the $\mathrm{C}: \mathrm{N}$ ratio of the order of 40-50 (Wetzel, 1975). Emergent parts of water plants show a considerably higher $\mathrm{C}: \mathrm{N}$ ratio, about 25 , than the submerged macrophytes having values about 5-10 (Stangenberg, 1949). In Lake Kahala sediments the $\mathrm{C}: \mathrm{N}$ ratio is about 12 at a depth of $4.5-5.5 \mathrm{~m}$ decreasing upwards to 9. Most 


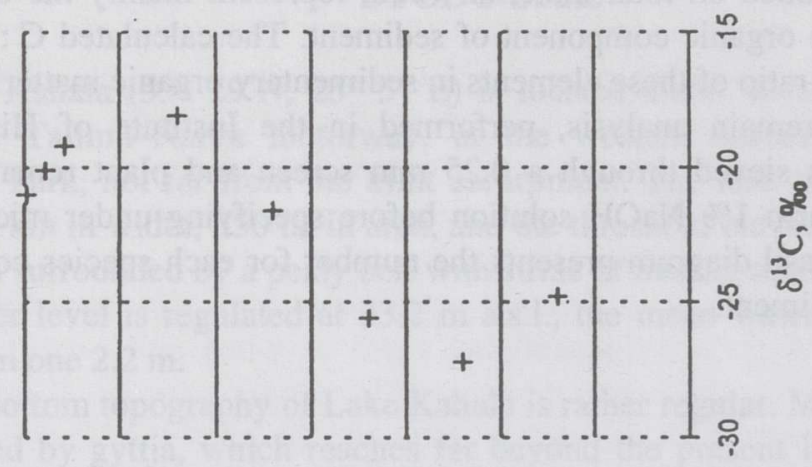

苞
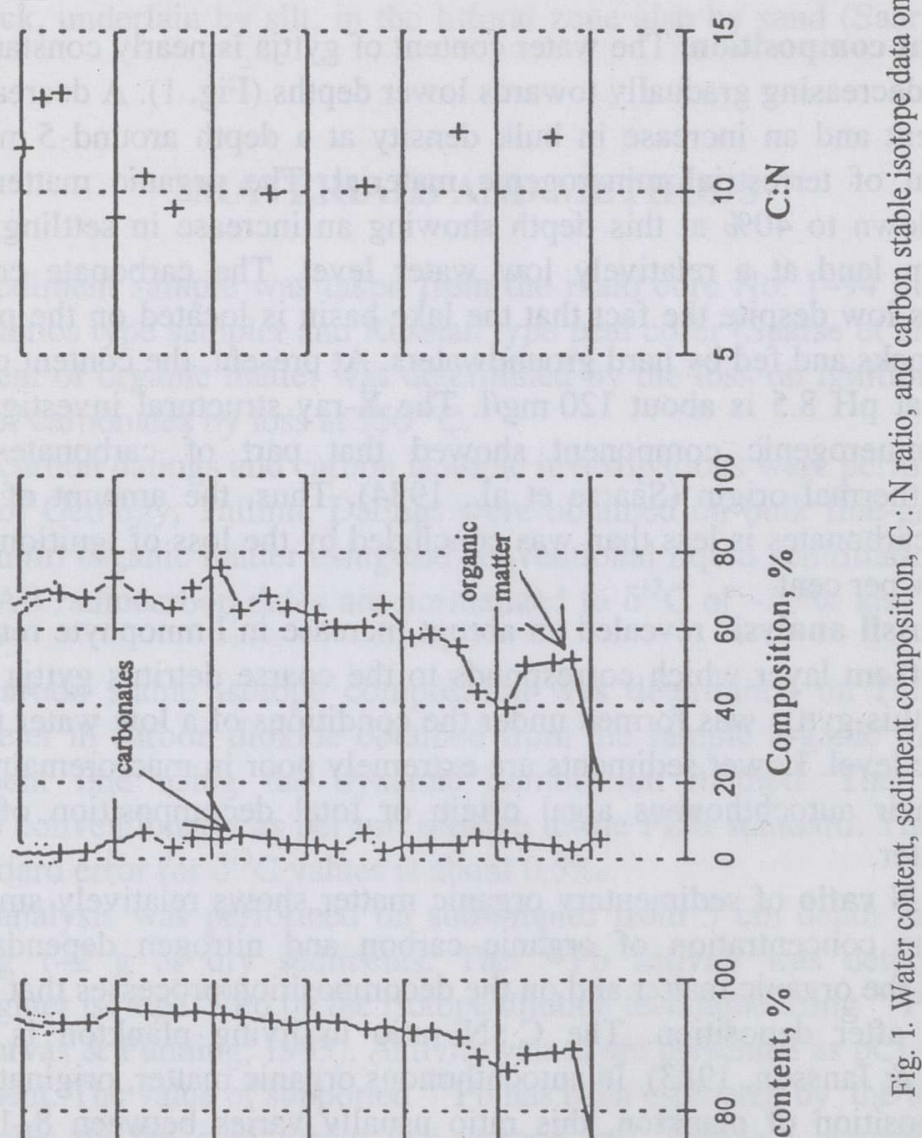
probably, this trend depicts the decreasing accumulation of terrestrial organic matter and remains of emergent aquatic plants in gyttja during the lake development. The higher $\mathrm{C}: \mathrm{N}$ ratio in the upper $0.5 \mathrm{~m}$ sediment unit seemingly results from an abrupt change in lake biota and in enhanced supply of organic matter from the lake catchment.

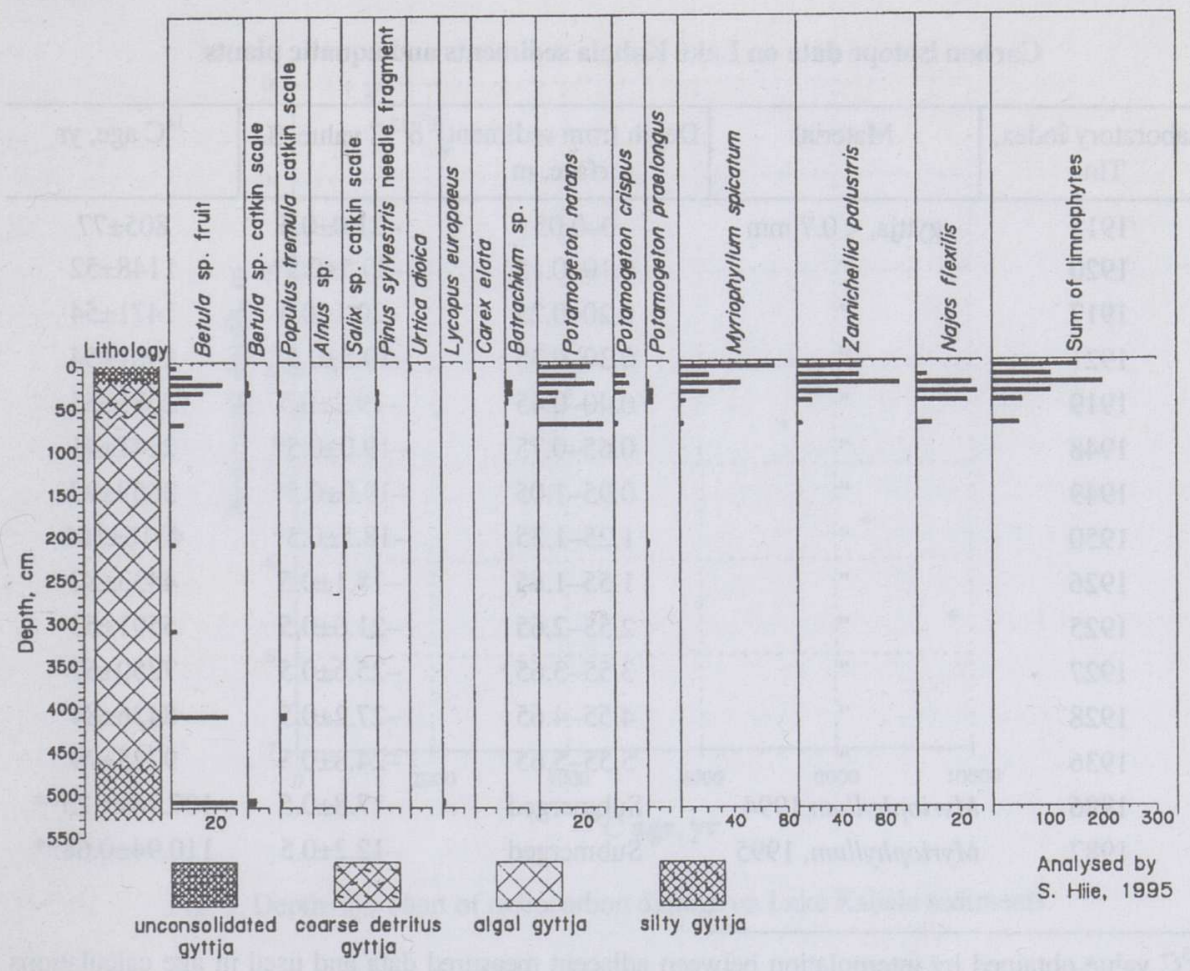

Fig. 2. Macrofossil diagram on Lake Kahala sediments.

Stable carbon isotope data on bulk sedimentary organic matter reveal significant changes in $\delta^{13} \mathrm{C}$ values with the total range of $9 \%$ (Table 1). The $\delta^{13} \mathrm{C}$ of -25 to $-27 \%$ at the depth interval of $3.5-4.65 \mathrm{~m}$ are within the range of values for terrestrial, emergent aquatic, and littoral plants (Håkansson, 1985) which use directly atmospheric $\mathrm{CO}_{2}$ during photosynthesis. At first glance, these values suggest the presence of mainly allochthonous organic matter in sediments and, probably, relatively low autochthonous productivity. Organic carbon gradually becomes more enriched in ${ }^{13} \mathrm{C}$ upward in the core to the depth of $1.5 \mathrm{~m}$. This trend is interpreted as a result of enhanced deposition of remains from algae and submerged aquatic plants. Isotope data on the modern submerged 
plant Myriophyllum, showing values between -12 and -18\%o (Table 1), support this opinion. However, this fact has only indirect significance because of different biotic and hydrologic conditions in the lake in the past. Scattered $\delta^{13} \mathrm{C}$ data on the upper $0.5 \mathrm{~m}$ layer may reflect, like the $\mathrm{C}: \mathrm{N}$ ratio, changes in lake biota and in the supply of organic matter from the catchment.

Table 1

Carbon isotope data on Lake Kahala sediments and aquatic plants

\begin{tabular}{c|c|c|c|c}
\hline $\begin{array}{c}\text { Laboratory index, } \\
\text { Tln- }\end{array}$ & Material & $\begin{array}{c}\text { Depth from sediment } \\
\text { surface, } \mathrm{m}\end{array}$ & $\delta^{13} \mathrm{C}$ value, \%o & ${ }^{14} \mathrm{C}$ age, yr \\
\hline 1915 & gyttja, $<0.7 \mathrm{~mm}$ & $0-0.05$ & $-21.0 \pm 0.5$ & $805 \pm 77$ \\
1920 & $"$ & $0.10-0.15$ & $-20.5 \pm 0.5^{*}$ & $1148 \pm 52$ \\
1917 & $"$ & $0.20-0.25$ & $-20.1 \pm 0.5$ & $1471 \pm 54$ \\
1921 & $"$ & $0.30-0.35$ & $-19.5 \pm 0.5^{*}$ & $1901 \pm 54$ \\
1919 & $"$ & $0.40-0.45$ & $-19.2 \pm 0.5$ & $2083 \pm 53$ \\
1948 & $"$ & $0.65-0.75$ & $-19.0 \pm 0.5^{*}$ & $2247 \pm 41$ \\
1949 & $"$ & $0.95-1.05$ & $-19.0 \pm 0.5^{*}$ & $3659 \pm 97$ \\
1950 & $"$ & $1.25-1.35$ & $-18.5 \pm 0.5 *$ & $4016 \pm 106$ \\
1926 & $"$ & $1.55-1.65$ & $-18.1 \pm 0.5$ & $4433 \pm 82$ \\
1925 & $"$ & $2.55-2.65$ & $-21.6 \pm 0.5$ & $5591 \pm 53$ \\
1927 & $"$ & $3.55-3.65$ & $-25.6 \pm 0.5$ & $7250 \pm 67$ \\
1928 & $"$ & $4.55-4.65$ & $-27.2 \pm 0.5$ & $8436 \pm 84$ \\
1936 & & $5.55-5.65$ & $-24.8 \pm 0.5$ & $9725 \pm 79$ \\
1986 & Myriophyllum,1994 & Submerged & $-17.8 \pm 0.5$ & $107.74 \pm 1.25^{* *}$ \\
1987 & Myriophyllum, 1995 & Submerged & $-12.2 \pm 0.5$ & $110.94 \pm 0.68^{* *}$
\end{tabular}

$* \delta^{13} \mathrm{C}$ value obtained by interpolation between adjacent measured data and used in age calculations only;

** marks the activity level as part of modern carbon, $\%$.

Thirteen radiocarbon dates have been obtained on gyttja samples (Table 1). Datings from the depth interval of $5.5-1.0 \mathrm{~m}$ on the depth-age chart lie on a straight line (Fig. 3) reflecting a uniform sedimentation in the lake. These radiocarbon ages fit quite well with the generalized ages inferred from the regional pollen zones (Kajak et al., 1976; Raukas et al., 1995).

Though the Lake Kahala basin possesses the geological features to contribute to ${ }^{14} \mathrm{C}$ datings a hard water effect, the data obtained do not seem to be influenced by old carbon. Such state of the carbon cycle may arise in a shallow lake with a long water residence time. At that, the carbon isotopic composition of lake DIC must be in equilibrium with the atmospheric $\mathrm{CO}_{2}$. As follows from the datings, at 
depths of 1.0 and $0.7 \mathrm{~m}$ the sedimentation rate began to slow down. The accumulation of the upper $0.7 \mathrm{~m}$ sediment unit is probably influenced by two processes: first, an increased input of contemporary and older organic carbon and nutrients from the catchment as a result of intensive agricultural activity and, second, subsurface erosion and redeposition of soft gyttja accumulated during earlier periods. Both of these processes may cause scattering of radiocarbon ages.

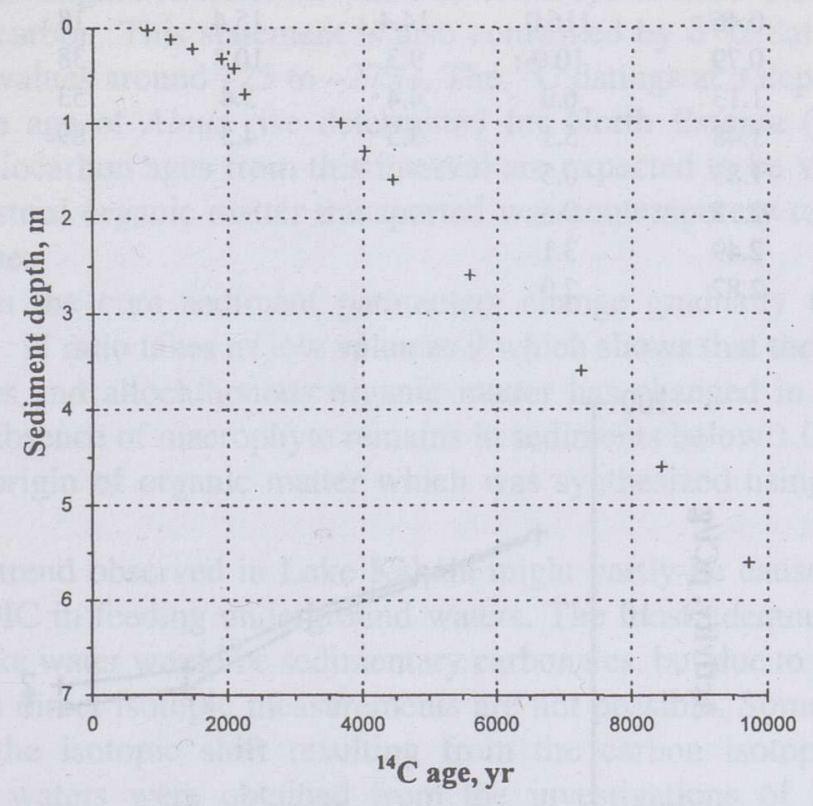

Fig. 3. Depth-age chart of radiocarbon datings on Lake Kahala sediments.

The ${ }^{210} \mathbf{P b}$ method is used for an independent study of the recent accumulation rate. The activity data measured are given in Table 2 and in the logarithmic chart of excess ${ }^{210} \mathrm{~Pb}$ on the mass-depth scale (Fig. 4). The distribution of these activity values is nearly linear, suggesting that the accumulation of the upper $0.25 \mathrm{~m}$ layer in Lake Kahala was rather uniform and that the subsurface layers are not disturbed by biomixing or sediment reworking processes. The CRS model for the supply of ${ }^{210} \mathrm{~Pb}$ into sediments was assumed. As the supported ${ }^{210} \mathrm{~Pb}$ values at the depth interval of $0.25-0.4 \mathrm{~m}$ show great irregularity, probably due to the redeposition of soft material, in the age calculation two different mean values of supported ${ }^{210} \mathrm{~Pb}$, and correspondingly two excess ${ }^{210} \mathrm{~Pb}$ values, were used (Table 2). Though there occur slight deviations in ages of different layers, the mean sedimentation rate is principally the same for both cases and equals to about $2.5 \mathrm{~mm} / \mathrm{yr}$. 
${ }^{210} \mathrm{~Pb}$ data on Lake Kahala sediments. Value of supported ${ }^{210} \mathrm{~Pb}$ is $1.55 \mathrm{pCi} / \mathrm{g}$ for excess I and $0.55 \mathrm{pCi} / \mathrm{g}$ for excess II

\begin{tabular}{c|c|c|c|c|c|c}
\hline $\begin{array}{c}\text { Midlevel of depth interval } \\
\text { from sediment surface }\end{array}$ & \multicolumn{3}{|c|}{${ }^{210} \mathrm{~Pb}$ activity, pCi/g } & \multicolumn{2}{c}{ Age, yr } \\
\hline $\begin{array}{c}\text { Linear, } \\
\mathrm{cm}\end{array}$ & $\begin{array}{c}\text { Mass-depth, } \\
\mathrm{g} / \mathrm{cm}^{2}\end{array}$ & Total & Excess I & Excess II & Excess I & Excess II \\
\hline 2.5 & 0.15 & 25.2 & 23.6 & 24.6 & modern & modern \\
7.5 & 0.46 & 116.0 & 14.4 & 15.4 & 18 & 17 \\
12.5 & 0.79 & 10.9 & 9.3 & 10.3 & 38 & 35 \\
17.5 & 1.13 & 6.0 & 4.4 & 5.4 & 53 & 48 \\
22.5 & 1.48 & 5.1 & 3.5 & 4.5 & 89 & 84 \\
27.5 & 1.83 & 0.5 & & & & \\
32.5 & 2.17 & 0.6 & & & & \\
37.5 & 2.49 & 3.1 & & & & \\
42.5 & 2.82 & 2.0 & & & &
\end{tabular}

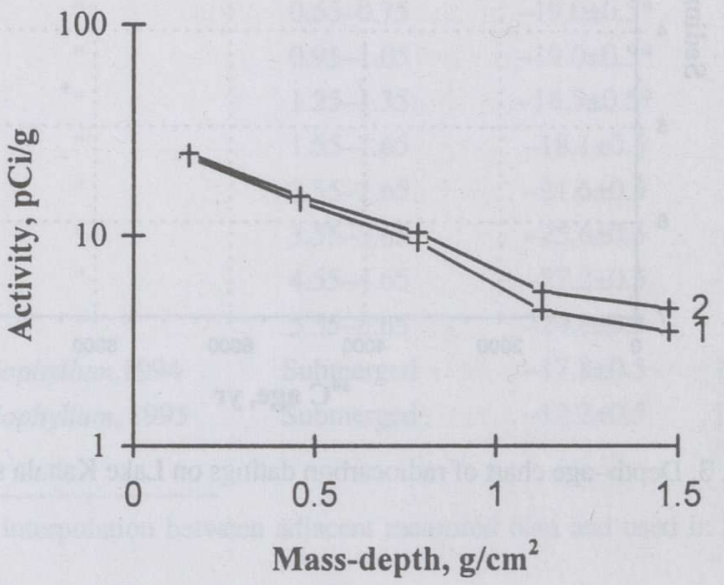

Fig. 4. Excess ${ }^{210} \mathrm{~Pb}$ data on Lake Kahala sediments. 1, value of supported ${ }^{210} \mathrm{~Pb}$ equals to $1.55 \mathrm{pCi} / \mathrm{g}$; 2, value of supported ${ }^{210} \mathrm{~Pb}$ equals to $0.55 \mathrm{pCi} / \mathrm{g}$.

\section{DISCUSSION}

The radiocarbon datings do not need any correction if sediment organic carbon consists of contemporaneous terrestrial plant material and if DIC in lake water used for autochthonous photosynthesis is in isotopic equilibrium with the atmospheric $\mathrm{CO}_{2}$. There are, however, very limited possibilities to prove that sediments do not contain organic material reworked from older deposits from the catchment. The isotopic composition of DIC in lake water depends on a complex 
of palaeoconditions: trophical state of the lake, supply of allochthonous dissolved organic carbon, hydrological regime, concentration and composition of DIC in feeding waters, etc.

The data obtained for Lake Kahala sediments indicate that in the lake history there were periods of different carbon sedimentation regimes. A relatively high content of minerogenic matter at the depth interval of 4.6-5.3 m arises from the intense allochthonous input which could comprise organic matter as well. At this depth the $\mathrm{C}: \mathrm{N}$ ratio amounts to 12 suggesting that great part of sedimentary organic matter originates from the plant material synthesized directly from the atmospheric carbon. This statement is also confirmed by $\delta^{13} \mathrm{C}$ data which show approximate values around -25 to $-27 \%$. The ${ }^{14} \mathrm{C}$ datings at a depth of $5.6 \mathrm{~m}$ fit well with the age of Alnus rise determined for North Estonia (Veski, 1992). Thus, the radiocarbon ages from this interval are expected to be valid assuming that the terrestrial organic matter transported was contemporary to the sediment formation time.

Upward in the core sediment parameters change gradually to a depth of $1.0 \mathrm{~m}$. The $\mathrm{C}: \mathrm{N}$ ratio takes as low value as 9 which shows that the proportion of autochthonous and allochthonous organic matter has changed in favour of the former. The absence of macrophyte remains in sediments below $1.0 \mathrm{~m}$ refers also to the algal origin of organic matter which was synthesized using DIC in lake water.

The $\delta^{13} \mathrm{C}$ trend observed in Lake Kahala might partly be caused by isotopic changes of DIC in feeding underground waters. The most adequate reflector of DIC in the lake water would be sedimentary carbonates, but due to their very low concentration direct isotopic measurements are not possible. Some hints for the measure of the isotopic shift resulting from the carbon isotope changes in underground waters were obtained from the investigations of Estonian lake marls, according to which $\delta^{13} \mathrm{C}$ values vary in the range of $2-3 \%$ during the Holocene (Punning et al., 1984). Thus, it seems that the total range of changes of the $\delta^{13} \mathrm{C}$ values found for Lake Kahala are mainly caused by biochemical isotopic effects.

In case of isotopic equilibrium between DIC and atmospheric $\mathrm{CO}_{2}$, the $\delta^{13} \mathrm{C}$ of $\mathrm{CO}_{2}$ dissolved in lake water should be about $-8 \%$ and that of $\mathrm{HCO}_{3}$ about $-1 \%$ o. $\mathrm{A} \mathrm{C}_{3}$ plant using such $\mathrm{CO}_{2}$ and showing normal isotopic fractionation effect about -18 to $-20 \%$ o should have a $\delta^{13} \mathrm{C}$ value around -25 to $-27 \%$ o (Deines, 1980). However, the isotopic fractionation effect in submerged aquatic plants tends to diminish depending on the plant type (algal or bryophyte) and on the availability of $\mathrm{CO}_{2}$ in lake water (Calder \& Parker, 1973; Smith \& Walker, 1980). Additionally, algae can assimilate $\mathrm{HCO}_{3}$ as a carbon source (Lucas, 1975). These physiological isotopic effects cause $\delta^{13} \mathrm{C}$ values of autochthonous organic matter higher than $-25 \%$.

At an isotopic disequilibrium, which can take place under the influence of DIC in feeding waters having the $\delta^{13} \mathrm{C}$ value of $-12 \%$ or lower, the DIC in lake 
water is also depleted in ${ }^{13} \mathrm{C}$. If in such lake autochthonous plants show normal isotopic fractionation, the $\delta^{13} \mathrm{C}$ of organic matter should be less than -25 to $-27 \%$. However, in the case of diminished isotopic fractionation the $\delta^{13} \mathrm{C}$ values may also be around $-25 \%$ or even higher. For that reason, stable carbon isotope data on bulk sedimentary organic matter, above $-25 \%$, may, but not unambiguously, affirm the isotopic equilibrium between the lake and atmospheric carbon.

Thus, the $\delta^{13} \mathrm{C}$ data on Lake Kahala sediments support, although not unambiguously, the validity of ${ }^{14} \mathrm{C}$ ages which was concluded also on the basis of pollen stratigraphy. The results of our (Saarse et al., 1990; Saarse \& Rajamäe, in press), as well as other investigations (Aravena et al., 1992), suggest a general empirical regularity, according to which the isotopically enriched sediment carbon, as compared with the terrestrial one, refers to approximate isotopic equilibrium between the lake DIC and atmosphere. Particularly intensive carbon exchange through the water-atmosphere boundary can take place in a shallow lake having a long water residence time, and which is located on an open landscape where the wave activity causes a strong water mixing.

The datings at depths of 0.7 and $1.0 \mathrm{~m}$ indicate a significant decrease in the sedimentation rate which could result from oligotrophication of the lake. A decrease in the trophic level is presumed to be a characteristic feature of the natural lake development during the Holocene, at least in Southern Sweden (Digerfeldt, 1977). For Estonian lakes, however, no direct hints for such regular change have been observed. Still, in Lake Kahala the general distribution of ${ }^{14} \mathrm{C}$ ages on the upper $0.7 \mathrm{~m}$ sediment unit refers to a decrease in the accumulation rate.

Notable influence of older carbon appears from ${ }^{14} \mathrm{C}$ datings for the upper $0.25 \mathrm{~m}$. Surface deposit has a ${ }^{14} \mathrm{C}$ age about $800 \mathrm{yr}$ and sediments at a depth of $0.20-0.25 \mathrm{~m}$ about $1470 \mathrm{yr}$. The ${ }^{210} \mathrm{~Pb}$ method gave an age about $100 \mathrm{yr}$ for the layer at a depth of $0.20-0.25 \mathrm{~m}$. Thus, the error of ${ }^{14} \mathrm{C}$ datings varies between about 800 and $1400 \mathrm{yr}$. Radiocarbon datings from the depth interval of 0.30 $0.70 \mathrm{~m}$, varying around $2000 \mathrm{yr}$, obviously consist also in some error. The data on sediment parameters obtained, however, are too scarce to reveal its measure. If the sedimentation rate for the whole detritus gyttja layer corresponding to the depth interval of $0-0.58 \mathrm{~m}$ was as high as that determined by the ${ }^{210} \mathrm{~Pb}$ method, then the ${ }^{14} \mathrm{C}$ age of a sample at a depth of $0.40-0.45 \mathrm{~m}$ would be greater by about $1800 \mathrm{yr}$. On the other hand, one can assume jerky changes in the sedimentation rate which could be observed at complex settling-redeposition conditions in the last stages of lake development. Probably, at a low water depth in the lake which is situated near the bedrock escarpment, klint, the wave action, particularly at storms, could facilitate subsurface erosion and redeposition of soft gyttja accumulated during earlier periods. As a result, ${ }^{14} \mathrm{C}$ ages from the upper $0.70 \mathrm{~m}$ bed are highly scattering, thus having a low value for chronological purposes. Irregular ${ }^{210} \mathrm{~Pb}$ activity data from a depth of $0.25-0.45 \mathrm{~m}$ testify also that partly 
soft sediments are strongly reworked. However, by ${ }^{210} \mathrm{~Pb}$ chronology sediments from the upper $0.25 \mathrm{~m}$ are not affected by redeposition processes. This is probably due to the dense stand of submerged plants, mainly Myriophyllum species, developed in the course of recent eutrophication.

\section{CONCLUSIONS}

The data on sediment composition show that the development of Lake Kahala has proceeded under variable limnological conditions causing also changes in the lake carbon cycle. During the initial stage of the accumulation of organic gyttja a relatively high content of allochthonous material is characteristic of the bottom deposits. ${ }^{14} \mathrm{C}$ dates on this sediment interval do not seem to be influenced by old carbon. Thus, assuming that allochthonous matter transported into the basin was contemporaneous with the sediment formation age, radiocarbon dates show high validity.

A decrease in the $\mathrm{C}: \mathrm{N}$ ratio, lack of macrofossils, and enrichment of organic matter in ${ }^{13} \mathrm{C}$ observed for upper sediments suggest an increase in lake productivity associated with higher input to sediments of autochthonous organic matter. The $\delta^{13} \mathrm{C}$ values obtained support the conclusion (however, not unambiguously) that DIC in lake water, serving as the source of carbon for submerged aquatic plants, was nearly in isotopic equilibrium with the atmospheric $\mathrm{CO}_{2}$ and that radiocarbon dates may be valid. Correlation of ${ }^{14} \mathrm{C}$ ages with pollen assemblage zones shows that in the depth interval of $1.0-5.7 \mathrm{~m}$ ${ }^{14} \mathrm{C}$ ages are in accordance with the chronology of regional pollen stratigraphy. Thus, though radiocarbon ages do not specify more precisely the sediment chronology in Lake Kahala, they, still, support the established regional chronostratigraphy.

Data on the upper $1.0 \mathrm{~m}$ sediment bed refer to notable changes in sediment accumulation. The general trend of ${ }^{14} \mathrm{C}$ ages display a decrease in the sedimentation rate. Scattering of datings can be explained by subsurface erosion and redeposition processes of soft gyttja accumulated during earlier periods, which decreases the chronological value of ${ }^{14} \mathrm{C}$ ages. Still, as the ${ }^{210} \mathrm{~Pb}$ data show, at an abundant stand of submerged plants in the recent eutrophication the deposition of sediments is not affected by reworking processes and has the rate as high as $2.5 \mathrm{~mm} / \mathrm{yr}$.

\section{ACKNOWLEDGEMENTS}

Financial support for this study was provided by EC through the PACT Project "Environmental history of the Baltic regions". The authors express their gratitude to Anto Raukas and Rein Vaikmäe for critical remarks. Special thanks 
are due to Sirje Hiie for identifying macrofossils, to Lilja Lahe for chemical analysis, to Mart Varvas for carrying out ${ }^{210} \mathrm{~Pb}$ dating, and to Helle Kukk for linguistic help.

\section{REFERENCES}

Aravena, R., Warner, B. G., MacDonald, G. M. \& Hanf, K. I. 1992. Carbon isotope composition of lake sediments in relation to lake productivity and radiocarbon dating. Quat. Res., 37, 333345.

Buchardt, B. \& Fritz, P. 1980. Environmental isotopes as environmental and climatological indicators. In Handbook of Environmental Isotope Geochemistry. Vol. 1. The Terrestrial Environment (Fritz, P. \& Fontes, J. Ch., eds.). Elsevier, 473-504.

Calder, J. A. \& Parker, P. L. 1973. Geochemical implications of induced changes in ${ }^{13} \mathrm{C}$ fractionation by blue-green algae. Geochim. Cosmochim. Acta, 37, 133-140.

Deines, P. 1980. The isotopic composition of reduced organic carbon. In Handbook of Environmental Isotope Geochemistry. Vol. 1. The Terrestrial Environment (Fritz, P. \& Fontes, J. Ch., eds.). Elsevier, 329-406.

Digerfeldt, G. 1977. The Flandrian Development of Lake Flarken. Regional Vegetation History and Palaeolimnology. Report LUNBDS/(NBGD-7013). University of Lund.

Håkansson, S. 1979. Radiocarbon activity in submerged plants from various South Swedish lakes. In Radiocarbon Dating (Berger, R. \& Suess, H., eds.). University of California Press, 433443.

Håkansson, S. 1985. A review of various factors influencing the stable carbon isotope ratio of organic lake sediments by the change from glacial to post-glacial environmental conditions. Quat. Sci. Rev., 4, 135-146.

Håkansson, L. \& Jansson, M. 1983. Principles of Lake Sedimentology. Springer Verlag, Berlin.

Kajak, K., Kessel, H., Liivrand, E., Pirrus, R., Raukas, A. \& Sarv, A. 1976. Mestnaya rabochaya stratigraficheskaya skhema chetvertichnykh otlozhenij Estonii. In Stratigrafiya chetvertichnykh otlozhenij Pribaltiki. Pargale, Vilnius, 4-52 (in Russian).

Lucas, W. J. 1975. The influence of light intensity on the activation and operation of the hydroxyl efflux of Chara corallina. J. Exp. Bot., 26, 347-360.

Olsson, I. 1986. Radiometric dating. In Handbook of Holocene Palaeoecology and Palaeohydrology (Berglund, B. E., ed.). John Wiley \& Sons, Chichester, Great Britain, 273-312.

Punning, J.-M., Martma, T. \& Vaikmäe, R. 1984. Light isotope variations in carbonate sediments and their palaeogeographical value. ZFI Mitteilungen, 84, 329-336.

Raukas, A., Saarse, L. \& Veski, S. 1995. A new version of the Holocene stratigraphy in Estonia. Proc. Estonian Acad. Sci. Geol., 44, 4, 201-210.

Saarse, L., Heinsalu, A., Poska, A., Veski, S. \& Rajamäe, R. Palaeoecology and human impact in the vicinity of Lake Kahala, North Estonia. PACT (in press).

Saarse, L. \& Rajamäe, R. Holocene vegetation and climate on the Haanja Heights, SE Estonia. Proc. Estonian Acad. Sci. Geol. (in press).

Saarse, L., Utsal, K. \& Lõokene, E. 1984. Application of the X-ray method for the study of the composition of gyttja. Proc. Acad. Sci. ESSR. Geol., 33, 1, 19-26 (in Russian).

Saarse, L., Vishnevskaya, Y., Sarv, A. \& Rajamäe, R. 1990. Evolution of the lakes of Saaremaa Island. Proc. Estonian Acad. Sci. Biol., 39, 1, 34-45 (in Russian).

Smith, F. A. \& Walker, N. A. 1980. Photosynthesis by aquatic plants: Effects of unstirred layers in relation to assimilation of $\mathrm{CO}_{2}$ and $\mathrm{HCO}_{3}$ and to carbon isotopic discrimination. New Phytol., 86, 245-259. 
Stangenberg, M. 1949. Nitrogen and carbon in the bottom-deposits of lakes and in the soils under carp-ponds. Internat. Ver. Limnol., 10, 422-437.

Törnqvist, T. E., de Jong, A. F. M. \& van der Borg, K. 1990. Comparison of AMS ${ }^{14} \mathrm{C}$ ages of organic deposits and macrofossils: A progress report. Nucl. Instr. Meth., B52, 442-445.

Turner, J. V., Fritz, P., Karrow, P. F. \& Warner, B. G. 1983. Isotopic and geochemical composition of marl lake waters and implications for radiocarbon dating of marl lake sediments. Canad. J. Earth Sci., 20, 599-615.

Varvas, M. \& Punning, J.-M. 1993. Use of the ${ }^{210} \mathrm{~Pb}$ method in studies of the development and human-impact history of some Estonian lakes. The Holocene, 3, 1, 34-44.

Veski, S. 1992. The Holocene Development of Lake Maardu and the Vegetational History of North-Estonia. Kvartärgeologiska Avdelningen, Uppsala Universitet, Licentiat-Thesis, 165.

Wetzel, R. G. 1975. Limnology. W. B. Saunders Company, Philadelphia.

\title{
SÜSINIKU GEOKEEMIA JA KAHALA JÄRVE SETETE KRONOLOOGIA
}

\section{Raivo RAJAMÄE, Leili SAARSE, Tõnu MARTMA, Atko HEINSALU, Anneli POSKA ja Siim VESKI}

Süsiniku geokeemilise ringe rekonstrueerimisel ja ${ }^{14} \mathrm{C}$-dateeringute põhjendamisel on kasutatud $\delta^{13} \mathrm{C}, \mathrm{C}: \mathrm{N}$, sette koostise, makrojäänuste ja ${ }^{210} \mathrm{~Pb}$ dateerimise tulemusi. ${ }^{14} \mathrm{C}$-dateeringud on valdavalt heas kooskõlas regionaalsete õietolmutsoonide vanusega. Dateeringute hajuvus ja lahknevus sette ülemises, $1 \mathrm{~m}$ paksuses kihis on ilmselt põhjustatud selle erosioonist ja hilisemast ümbersetitamisest, mis on omane suhteliselt suurtele, kuid madalatele järvedele.

\section{ГЕОХИМИЯ УГЛЕРОДА И ХРОНОЛОГИЯ ДОННЫХ ОТЛОЖЕНИЙ ОЗЕРА КАХАЛА}

\author{
Райво РАЯМЯЭ, ЛейЛи СААРСЕ, Тыну МАРТМА, \\ Атко ХЕЙНСАЛУ, АннеЛИ ПОСКА и СИЙМ ВЕСКИ
}

В целях реконструкции геохимического круговорота углерода и обоснования радиоуглеродных данных были использованы показатели $\delta^{13} \mathrm{C}, \mathrm{C}: \mathrm{N}$, состава отложений, макроостатков и ${ }^{210} \mathrm{~Pb}$ датировок. Полученные радиоуглеродные датировки в общем хорошо согласуются с возрастом палинологических зон. Исключение составляет верхняя метровая часть разреза, радиоуглеродный возраст которой явно моложе. Причина кроется, видимо, в том, что более древние донные осадки в довольно крупных, но мелких озерах больше подвержены эрозии и переотложению. 